\title{
PENGGUNAAN PESTISIDA DAN STRATEGI PENGELOLAAN HAMA PADI DI DESA BALUNG LOR KECAMATAN BALUNG KABUPATEN JEMBER
}

Oleh :

SURATNO dan M.SYARIEF *)

\begin{abstract}
ABSTRAK
Penelitian ini bertujuan untuk mengetahui pengaruh tingkat pendidikan formal petani padi terhadap penggunaan pestisida dan strategi pengelolaan hama padi di Desa Balung Lor, Kecamatan Balung, Kabupaten Jember. Data dikumpulkan dengan teknik wawancara langsung menggunakan kuesioner terhadap 25 orang petani pemilik. Analisis data menggunakan metode deskriptif analitis statistis non parametrik uji satu sampel Kolmogorov-Smirnov. Korelasi antar tingkat pendidikan menggunakan analisis Rank Spearman's . Kesimpulan penelitian sebagai berikut: penggunaan pestisida berada pada level tinggi. Faktor pendidikan formal, berpengaruh terhadap tingkat penggunaan pestisida dan pengambilan keputusan pengendalian hama. Penggunaan pestisida pada level tinggi, ketidak pahaman tentang teknik penggunaan perstisida dan penggunaan pestisida secara tidak benar, banyak dilakukan oleh petani berpendidikan tidak tamat sekolah dasar dan sekolah Dasar.
\end{abstract}

Kata kunci: pendidikan petani, penggunaan pestisida. 
Suratno dan M.Syarief, Penggunaan Pestisida Dan Strategi Pengelolaan Hama Padi Di Desa Balung Lor Kec.Balung Kab. Jember

\section{PENDAHULUAN}

Pendekatan yang digunakan dalam pengendalian hama terpadu (PHT) saat ini umumnya hanya terkait dengan tujuan pencapaian skala dan keuntungan jangka pendek, sebaliknya pada pendekatan pengelolaan hama berbasis ekologis (ecologically based pest management) tujuan akhir sistem produksi yang akan dicapai adalah rancangan agroekosistem yang secara ekonomi menguntungkan dan secara ekologis berkelanjutan. Pengelolaan serangga hama di masa datang sudah harus direvisi secara menyeluruh, yaitu dari pendekatan PHT menjadi pengelolaan hama berbasis ekologis. Hal ini menjadikan pemantauan penggunaan pestisida dalam pengelolaan suatu jenis hama dalam suatu agroekosistem tanaman budidaya menjadi penting dilakukan (Metcalf, 1974).

Pemerintah mengharapkan dalam rangka penggunaan pestisida dilaksanakan secara benar sesuai dengan aturan yang telah direkomendasikan. Namun aplikasi pestisida secara langsung di lapangan masih terbentur oleh beberapa faktor diantaranya faktor pendidikan petani, sikap petani terhadap peraturan penggunaan pestisida dan tindakan penggunaannya (Sulistiyono dkk., 2008).

Secara sosial dan ekonomi penggunaan pestisida yang dilakukan secara tidak benar akan berdampak terhadap ekonomi petani dan lingkungan. Petani harus mengeluarkan biaya yang lebih banyak untuk pengendalian hama karena takaran dan frekuensi penggunaan pestisida yang telah diaplikasikan sebelumnya tidak dapat lagi mengatasi permasalahan hama yang menyerang tanaman (Untung, 2004). Dosis yang semakin tinggi dan frekuensi semaking sering akan mengakibatkan semakin tingginya biaya produksi.

Permasalahannya, sebagian besar peningkatan resistensi hama terhadap pestisida disebabkan oleh tindakan manusia terutama dalam pengaplikasiannya tanpa dilandasi pengetahuan tentang organisme pengganggu tanaman (OPT) yang menyerang. Pemilihan jenis pestisida yang dilakukan petani pada umumnya diperoleh dari toko pestisida. Petani kurang memahami tentang teknik penggunaan pestisida secara aman dan efektif, yaitu tepat dalam pemilihan pestisida (sesuai dengan OPT dan telah direkomendasikan oleh Komisi Pestisida), tepat konsentrasi dan dosis, tepat alat yang digunakan dan tepat waktu aplikasinya (Ditjen Bina Sarana Produksi Pertanian, 2005).

Faktor-faktor yang dapat mempengaruhi lemahnya hubungan antara sikap dan tindakan petani adalah:

1) Anxienty artinya petani merasa cemas jika terjadi kegagalan panen yang mengakibatkan nilai investasi yang tidak kembali.

2) Forcasting, lemahnya kemampuan petani untuk memprediksi serangan OPT. sehingga kecenderungan melakukan pengendalian secara terjadwal;

3) Petani tidak melakukan monitoring OPT secara berkesinambungan

4) Internal Conflic, faktor internal yang paling berpengaruh adalah antara pemenuhan kebutuhan dan kendala usahanya, gangguan OPT dapat menimbulkan kekawatiran yang selanjutnya menimbulkan kecemasan, sehingga mendorong petani bertindak yang tidak terarah dalam mengaplikasikan pestisida (Sarwono, 1999).

Penelitian ini bertujuan untuk mengetahui pengaruh tingkat pendidikan formal petani padi di Desa Balung Lor, Kecamatan Balung Kabupaten Jember terhadap tingkat penggunaan pestisida dan dasar pengambilan keputusan penggunaan pestisida.

\section{METODE PENELITIAN}

Penelitian ini dilaksanakan mulai Oktober sampai dengan Desember 2013, jumlah responden 25 orang petani pemilik sawah, menggunakan stratified sampling yang didasarkan pada tingkat pendidikan formal meliputi: tidak tamat SD (TTSD), tamat SD, tamat SMP, tamat SMA/SMK dan tamat perguruan tinggi (PT). 
Pengukuran tingkat penggunaan pestisida menggunakan skala Likert (Vredenbergt, 1978 dalam Kruniasih dan Paramita, 2006). Data dikumpulkan dengan teknik wawancara langsung menggunakan kuesioner. Cara pengukuran tingkat penggunaan pestisida dengan memcocokkan peraturan kriteria dengan aplikasi di tingkat petani: a. Bila penggunaan melebihi aturan maka tingkat penggunaan pestisida adalah tinggi;

b. Bila sesuai dengan aturan, maka tingkat penggunaan pestisida adalah tepat

c. Bila penggunaan kurang dari aturan maka tingkat penggunaan pestisida adalah rendah.

Tabel 1. Jenis kriteria dan skor tingkat penggunaan pestisida

\begin{tabular}{|l|l|c|c|c|}
\hline \multirow{2}{*}{ No } & \multirow{2}{*}{ Jenis kriteria } & \multicolumn{3}{|c|}{ Skor tingkat penggunaan pestisida } \\
\cline { 3 - 5 } & & Tinggi & Tepat & Rendah \\
\hline 1 & Jenis pestisida & 3 & 2 & 1 \\
\hline 2 & Dosis & 3 & 2 & 1 \\
\hline 3 & Frekuensi penyemprotan & 3 & 2 & 1 \\
\hline 4 & Saat penyemprotan & 3 & 2 & 1 \\
\hline 5 & Rotasi pestisida & 3 & 2 & 6 \\
\hline \multicolumn{2}{|c|}{ Total skor } & 15 & 10 & \\
\hline
\end{tabular}

Kriteria dan skor tingkat penggunaan pestisida sebagai berikut: $5-8$ rendah, $9-12$ tepat dan $13-16$ tinggi (Kruniasih dan paramita, 2006).

Dasar pengambilan keputusan penggunaan pestisida disajikan dalam Tabel 2 berikut.

Tabel 2. Strategi pengendalian dan skor dasar pengambilan keputusan

\begin{tabular}{|c|l|c|c|c|}
\hline \multirow{2}{*}{ No } & \multicolumn{2}{|c|}{ Strategi pengendalian } & \multicolumn{2}{|c|}{ Skor dasar pengambilan keputusan penggunaan pestisida } \\
\cline { 3 - 5 } & & $\begin{array}{c}\text { Paham dan } \\
\text { melakukan }\end{array}$ & $\begin{array}{c}\text { Paham dan tidak } \\
\text { melakukan }\end{array}$ & $\begin{array}{c}\text { Tidak paham dan } \\
\text { tidak melakukan }\end{array}$ \\
\hline 1 & Pertumbuhan tanaman sehat & 3 & 2 & 1 \\
\hline 2 & Agensia pengendali hayati & 3 & 2 & 1 \\
\hline 3 & Varietas tahan OPT & 3 & 2 & 1 \\
\hline 4 & Secara fisik dan mekanik & 3 & 2 & 1 \\
\hline 5 & Secara genetik & 3 & 2 & 1 \\
\hline 6 & Pestisida & 3 & 2 & 6 \\
\hline & Total skor & 18 & 12 & \\
\hline
\end{tabular}

Kriteria dasar pengambilan keputusan petani sebagai berikut: 5 - 9 tidak paham, sehingga tidak melakukan, 10 - 14 paham tetapi tidak melakukan dan 15 - 19 tinggi (Kruniasih dan paramita, 2006).

Pengujian hipotesis tingkat penggunaan pestisida menggunakan analisis non parametrik uji satu sampel Kolmogorov-Smirnov. Hipotesis yang digunakan adalah: H0: jika f1 = f2 = f3 (tidak ada perbedaan tingkat penggunaan pestisida). $\mathrm{H} 1$ : jika $\mathrm{fl} \neq$ $\mathrm{f} 2 \neq \mathrm{f} 3$ (ada perbedaan tingkat penggunaan pestisida). $\mathrm{f} 1=$ tinggi, $\mathrm{f} 2=$ tepat dan $\mathrm{f} 3=$ rendah. Kriteria pengujian taraf signifikansi: jika $\mathrm{D}$ hitung $\leq \mathrm{D}$ tabel maka $\mathrm{H} 0$ diterima dan $\mathrm{H} 1$ ditolak, jika $\mathrm{D}$ hitung $\geq \mathrm{D}$ tabel maka $\mathrm{H} 0$ ditolak dan $\mathrm{H} 1$ diterima (Kruniasih dan Paramita, 2006).

Pengujian hipotesis dasar pengambilan keputusan penggunaan pestisida menggunakan analisis non parametrik uji satu sampel Kolmogorov-Smirnov. Hipotesis yang digunakan adalah:

H0: jika $\mathrm{f} 1=\mathrm{f} 2=\mathrm{f} 3$ (tidak ada perbedaan dalam pengambilan keputusan). H1: jika $\neq \mathrm{f} 2 \neq \mathrm{f} 3$ (ada perbedaan dalam pengambilan keputusan). $\mathrm{f} 1$ = paham dan melakukan, $\quad \mathrm{f} 2$ = paham tetapi tidak melakukan dan $\mathrm{f} 3=$ tidak paham dan tidak melakukan. Kriteria pengujian taraf signifikansi: jika D hitung $\leq \mathrm{D}$ tabel maka $\mathrm{H} 0$ diterima dan $\mathrm{H} 1$ ditolak, jika $\mathrm{D}$ hitung $\geq \mathrm{D}$ tabel maka $\mathrm{H} 0$ ditolak dan H1 diterima (Kruniasih dan Paramita, 2006).

Korelasi tingkat pendidikan dan tingkat penggunaan pestsisida dan dasar pengambilan keputusan menggunakan pestisida dianalisis menggunakan analisis Rank Spearman's. Kategori koefisien korelasi sebagai berikut: $\rho=1$ : korelasi 
Suratno dan M.Syarief, Penggunaan Pestisida Dan Strategi Pengelolaan Hama Padi Di Desa Balung Lor Kec.Balung Kab. Jember

positif sempurna; $0.80 \leq \rho<1$ : korelasi tinggi sekali; $0.60 \leq \rho<0.80$ : korelasi tinggi; $0.40 \leq \rho<0.60$ : korelasi sedang; $0.20 \leq \rho<0.40$ : korelasi rendah;
$0.00 \leq \rho<0.20$ : korelasi rendah sekali; $\rho=0$ : tidak mempunyai korelasi linear. Makin jauh $\rho$ dari nol, korelasinya makin tinggi ( Sulistyono dkk., 2008).

\section{HASIL DAN PEMBAHASAN}

Hasil uji Kolmogorov-Smirnov pada tingkat penggunaan pestisida, disajikan dalam Tabel 3 . berikut.

Tabel 3. Hasil uji Kolmogorov-Smirnov pada tingkat penggunaan pestisida

One-Sample Kolmogorov-Smirnov Test

\begin{tabular}{|c|c|c|}
\hline & & Pendidikan \\
\hline \multirow[t]{6}{*}{$\mathrm{N}$} & & 25 \\
\hline & Mean & 12.4000 \\
\hline & Std. Deviation & 3.82971 \\
\hline & Absolute & .282 \\
\hline & Positive & .174 \\
\hline & Negative & -.282 \\
\hline \multicolumn{2}{|c|}{ Kolmogorov-Smirnov Z } & 1.411 \\
\hline \multicolumn{2}{|c|}{ Asymp. Sig. (2-tailed) } & .037 \\
\hline
\end{tabular}

a Test distribution is Normal.

b Calculated from data.

Berdasarkan Tabel 4., nilai D hitung (0.282) > nilai D tabel (0.264), maka ada perbedaa tingkat penggunaan pestisida.

Hasil analisis Rank Spearman's korelasi antara tingkat pendidikan disajikan dalam Tabel 4. berikut.

Tabel 4. Korelasi tingkat antar pendidikan

\begin{tabular}{|c|c|c|c|c|c|c|c|}
\hline & & & TTSD & SD & SMP & SMA/SMK & PT \\
\hline \multirow[t]{13}{*}{$\begin{array}{l}\text { Spearman's } \\
\text { rho }\end{array}$} & TTS & $\begin{array}{l}\text { Correlation } \\
\text { Coefficient }\end{array}$ & 1.000 & $1.000(* *)$ & .866 & .866 & .866 \\
\hline & & Sig. (2-tailed) & & & .333 & .333 & .333 \\
\hline & & $\mathrm{N}$ & 3 & 3 & 3 & 3 & 3 \\
\hline & SD & $\begin{array}{l}\text { Correlation } \\
\text { Coefficient }\end{array}$ & $1.000(* *)$ & 1.000 & .866 & .866 & .866 \\
\hline & & Sig. (2-tailed) & & & .333 & .333 & .333 \\
\hline & & $\mathrm{N}$ & 3 & 3 & 3 & 3 & 3 \\
\hline & SMP & $\begin{array}{l}\text { Correlation } \\
\text { Coefficient }\end{array}$ & .866 & .866 & 1.000 & $1.000(* *)$ & $1.000(* *)$ \\
\hline & & Sig. (2-tailed) & .333 & .333 & & & \\
\hline & & $\mathrm{N}$ & 3 & 3 & 3 & 3 & 3 \\
\hline & $\begin{array}{l}\text { SMA/ } \\
\text { SMK }\end{array}$ & $\begin{array}{l}\text { Correlation } \\
\text { Coefficient }\end{array}$ & .866 & .866 & $1.000(* *)$ & 1.000 & $1.000(* *)$ \\
\hline & & Sig. (2-tailed) & .333 & .333 & . & . & . \\
\hline & & $\mathrm{N}$ & 3 & 3 & 3 & 3 & 3 \\
\hline & PT & $\begin{array}{l}\text { Correlation } \\
\text { Coefficient }\end{array}$ & .866 & .866 & $1.000(* *)$ & $1.000(* *)$ & 1.000 \\
\hline
\end{tabular}


Jurnal Ilmiah INOVASI, Vol.14 No.1 Hal. 46-52, Januari-April 2014, ISSN 1411-5549

\begin{tabular}{|l|r|r|r|r|r|} 
Sig. (2-tailed) & .333 & .333 &. &. &. \\
$\mathrm{~N}$ & 3 & 3 & 3 & 3 & 3 \\
\hline
\end{tabular}

** Correlation is significant at the 0.01 level (2-tailed).

mempengaruhi petani untuk menentukan sikap terhadap penggunaan pestisida.

Berdasarkan Tabel 4. Kekuatan korelasi $\rho$ hitung menunjukkan interpretasi sangat tinggi sampai sempurna antar tingkat pendidikan. Hal ini menunjukkan bahwa tingkat pendidikan mampu
Komposisi tingkat pendidikan dan tingkat penggunaan pestisida disajikan dalam Tabel 5. berikut.

Tabel 5. Komposisi tingkat pendidikan dan tingkat penggunaan pestisida (\%)

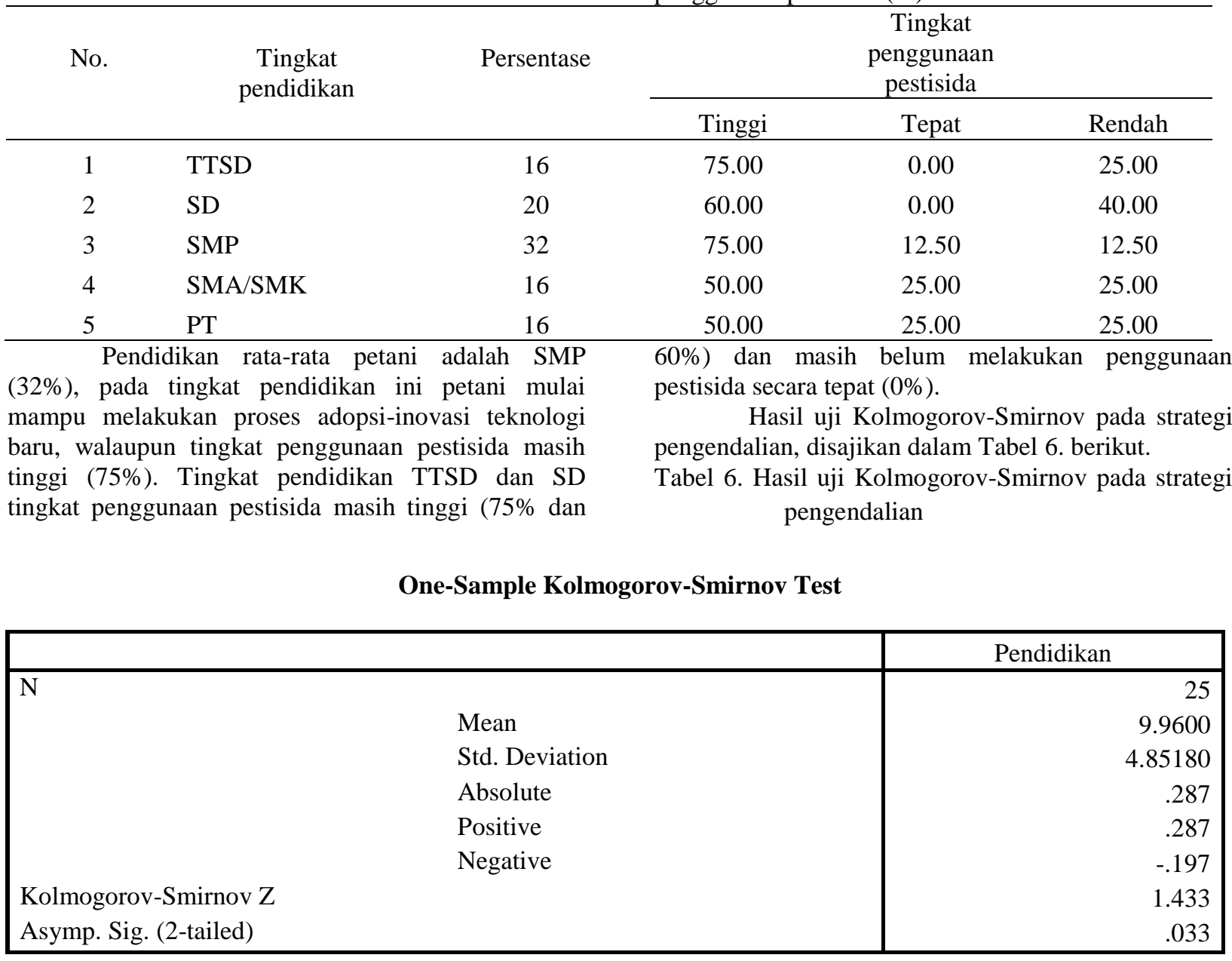

a Test distribution is Normal.

b Calculated from data.

Berdasarkan Tabel 6., nilai D hitung $(0.287)>$ nilai D tabel (0.264), maka ada pengaruh pendidikan terhadap dasar pengambilan keputusan penggunaan pestisida. Hasil analisis Spearman's antar tingkat pendidikan disajikan dalam 
Suratno dan M.Syarief, Penggunaan Pestisida Dan Strategi Pengelolaan Hama Padi Di Desa Balung Lor Kec.Balung Kab. Jember

Tabel 7. berikut.

Tabel 7. Korelasi antar tingkat pendidikan

Correlations

\begin{tabular}{|c|c|c|c|c|c|c|}
\hline & & TTSD & SD & SMP & SMA & PT \\
\hline \multirow[t]{3}{*}{ TTSD } & Pearson Correlation & 1 & .929 & .945 & .945 & .945 \\
\hline & Sig. (2-tailed) & & .242 & .212 & .212 & .212 \\
\hline & $\mathrm{N}$ & 3 & 3 & 3 & 3 & 3 \\
\hline \multirow[t]{3}{*}{ SD } & Pearson Correlation & .929 & 1 & .756 & .756 & .756 \\
\hline & Sig. (2-tailed) & .242 & & .454 & .454 & .454 \\
\hline & $\mathrm{N}$ & 3 & 3 & 3 & 3 & 3 \\
\hline \multirow[t]{3}{*}{ SMP } & Pearson Correlation & .945 & .756 & 1 & $1.000(* *)$ & $1.000(* *)$ \\
\hline & Sig. (2-tailed) & .212 & .454 & & .000 & .000 \\
\hline & $\mathrm{N}$ & 3 & 3 & 3 & 3 & 3 \\
\hline \multirow[t]{3}{*}{ SMA } & Pearson Correlation & .945 & .756 & $1.000(* *)$ & 1 & $1.000(* *)$ \\
\hline & Sig. (2-tailed) & .212 & .454 & .000 & & .000 \\
\hline & $\mathrm{N}$ & 3 & 3 & 3 & 3 & 3 \\
\hline \multirow[t]{3}{*}{ PT } & Pearson Correlation & .945 & .756 & $1.000(* *)$ & $1.000(* *)$ & 1 \\
\hline & Sig. (2-tailed) & .212 & .454 & .000 & .000 & \\
\hline & $\mathrm{N}$ & 3 & 3 & 3 & 3 & 3 \\
\hline
\end{tabular}

** Correlation is significant at the 0.01 level (2-tailed).

Berdasarkan Tabel 7. nilai korelasi $\rho$ hitung menunjukkan interpretasi sangat tinggi sampai dengan korelasi positip sempurna antar tingkat pendidikan. Hal ini menunjukkan bahwa tingkat pendidikan mampu mempengaruhi petani untuk menentukan strategi pengendalian.

Komposisi tingkat pendidikan dan dasar pengambilan keputusan penggunaan strategi disajikan dalam Tabel 8. berikut.

Tabel 8. Komposisi tingkat pendidikan dan strategi pengendalian (\%)

\begin{tabular}{llcccc}
\hline & \multirow{2}{*}{$\begin{array}{c}\text { Tingkat } \\
\text { No. }\end{array}$} & Pendidikan & & \multicolumn{3}{c}{$\begin{array}{c}\text { dasar pengambilan } \\
\text { keputusan penggunaan } \\
\text { pestisida }\end{array}$} \\
\cline { 3 - 6 } & & & $\mathrm{p}+\mathrm{tm}$ & $\mathrm{p}+\mathrm{m}$ \\
\cline { 3 - 6 } & & 16 & 75.00 & 25.00 & 0.00 \\
2 & TTSD & 20 & 60.00 & 40.00 & 0.00 \\
3 & SD & 32 & 75.00 & 12.50 & 12.50 \\
4 & SMA & 16 & 50.00 & 25.00 & 25.00 \\
5 & PT & 16 & 50.00 & 25.00 & 25.00 \\
\hline
\end{tabular}


Keterangan: $\mathrm{tp}+\mathrm{tm}=$ tidak paham dan tidak melakukan; $\mathrm{p}+\mathrm{tm}=$ paham tetapi tidak melakukan dan $\mathrm{p}+\mathrm{m}=$ paham dan melakukan.

Pendidikan rata-rata petani adalah SMP (32\%), pada tingkat pendidikan TTSD dan SD paham dan melakukan memiliki nilai $0.00 \%$. Strategi

pengendalian menggunakan pestisida mulai dilakukan oleh petani yang berpendidikan SMP walaupun persentasenya rendah $(12.5 \%)$. Pada pendidikan SMA/SMK dan PT sudah paham dan melakukan keputusan penggunaan pestisida secara benar $(25 \%)$.

Pendidikan berpengaruh terhadap daya nalar dan pikir petani (Cognitive). selanjutnya semakin tinggi jenjang pedidikan memiliki kemampuan lebih baik untuk menerima dan menelaah informasi yang diterima (Notoadmojo, 2003). Didukung Yasuko et al (2006). tingginya jenjang pendidikan mempunyai relevansi positif terhadap penentuan sikap. Hal ini sesuai dengan pendapat Mar'at 1994 dalam Sulistyono dkk., 2008, yang menyatakan bahwa terbentuknya sikap sangat dipengaruhi oleh aspek kemampuan Cognitif yang berupa pengetahuan.

\section{KESIMPULAN}

Penelitian berjudul “ Tingkat penggunaan pestisida petani padi desa balung lor kecamatan balung kabupaten jember" dapat dapat disimpulkan sebagai berikut:

1. Penggunaan pestisida oleh petani padi di Desa Balung Lor, Kecamatan Balung Kabupaten Jember berada pada level tinggi.

2. Faktor pendidikan formal, berpengaruh terhadap tingkat penggunaan pestisida dan pengambilan keputusan strategi pengendalian hama.

3. Penggunaan pestisida pada level tinggi, ketidak pahaman tentang teknik penggunaan perstisida dan penggunaan pestisida secara tidak benar, banyak dilakukan oleh petani berpendidikan tidak tamat sekolah dasar dan sekolah Dasar.

\section{DAFTAR PUSTAKA}

Ditjen Bina Sarana Produksi Pertanian, 2005. Jenis pestisida yang terdaftar di Deptan periode tahun 1997 - 2005. Jakarta: Direktorat Jenderal Bina Sarana Pertanian. Departemen Pertanian.

Kruniasih, I., S., Paramita. 2006. Penggunaan pestisida dalam pengendalian hama terpadu petani sayuran di Kecamatan Pakem Kabupaten Sleman Yogyakarta. Agros 8(1): $103-115$.

Mar'at, 1994. Perubahan sikap manusia dan pengukurannya. Jakarta: Balai Aksara.

Metcalf, R.L. 1974. Insecticide in Pest Management. New York:John Wiley and Sons, p. 235-274.

Notoatmodjo, 2003. Pendidikan dan perilaku kesehatan. Jakarta: Rineka Cipta.

Siegel, S. 1986. Statistic non parametric. Jakarta: Garamedia. 374 Hal.

Sulistiyono, 1., R. C. , Tarumingkeng, B. Sanim1 dan Dadang. 2008. Pengetahuan sikap dan tindakan petani bawang merah dalam penggunaan pestisida (studi kasus di kabupaten nganjuk propinsi jawa timur) ). J. Agroland 15 (1) :12 17.

Untung, K. 2004. Manajemen resistensi pestisida sebagai penerapan pengelolaan hama terpadu. Makalah seminar nasional manajemen resistensi pestisida dalam penerapan hama terpadu. Yogyakarta 24 - 25 Februari 2004. Yogyakarta: Fakultas Pertanian Universitas Gajahmada. 